Article

\title{
Palm Oil Conversion to Bio-Jet and Green Diesel Fuels over Cobalt Phosphide on Porous Carbons Derived from Palm Male Flowers
}

\author{
Napat Kaewtrakulchai ${ }^{1,2}$, Rungnapa Kaewmeesri ${ }^{1,3}$, Vorranutch Itthibenchapong ${ }^{1}$, \\ Apiluck Eiad-Ua ${ }^{2}$ and Kajornsak Faungnawakij ${ }^{1, *(\mathbb{D})}$ \\ 1 National Nanotechnology Center (NANOTEC), National Science and Technology Development \\ Agency (NSTDA), Pathum Thani 12120, Thailand; knapat.kara@gmail.com (N.K.); \\ rungnapa.kaewmeesri@gmail.com (R.K.); vorranutch@nanotec.or.th (V.I.) \\ 2 College of Nanotechnology, King Mongkut's Institute of Technology Ladkrabang, Bangkok 10520, Thailand; \\ apiluck.ei@kmitl.ac.th \\ 3 The Joint Graduate School of Energy and Environment (JGSEE), King Mongkut's University of \\ Technology Thonburi, Bangkok 10140, Thailand \\ * Correspondence: kajornsak@nanotec.or.th; Tel.: +66-2-564-7100 (ext. 6638); Fax: +66-2-564-6981
}

Received: 20 May 2020; Accepted: 15 June 2020; Published: 19 June 2020

\begin{abstract}
Porous carbon was successfully synthesized from palm male flowers (PMFs), using microwave-assisted potassium hydroxide $(\mathrm{KOH})$ activation and was used as a catalyst support for the conversion of palm oil into bio-hydrocarbons, in fractions of green diesel and bio-jet fuel. Palm male flower-derived porous carbon (PC), consolidated with well dispersed cobalt phosphide $(\mathrm{CoP})$ nanoparticles, was synthesized by simple wet-impregnation with subsequent thermal treatment. The physicochemical properties of the synthesized CoP/PC catalysts were evaluated by various techniques including proximate and ultimate elemental analysis, FTIR, XRD, $\mathrm{N}_{2}$ sorption, SEM, TEM-EDS, and $\mathrm{NH}_{3}$-temperature programmed desorption (TPD). The effects of the pyrolysis temperatures $\left(600-900^{\circ} \mathrm{C}\right)$, used for the impregnated samples before the reduction process, on catalyst properties and catalytic performance were investigated. Moreover, the effect of a liquid hourly space velocity of $0.5-1.5 \mathrm{~h}^{-1}$ and reaction temperatures of $340-420^{\circ} \mathrm{C}$ was studied in the palm oil conversion. The catalyst pyrolyzed at $600{ }^{\circ} \mathrm{C}$ possessed the greatest particle dispersion and surface area, and showed the highest yield of liquid hydrocarbon product (C9-C18). We also found that the high pyrolysis temperature above $800{ }^{\circ} \mathrm{C}$ partially transformed the $\mathrm{Co}_{2} \mathrm{P}$ phase into $\mathrm{CoP}$ one which significantly exhibited higher cracking activity and bio-jet selectivity, due to the improved acidity of the catalyst.
\end{abstract}

Keywords: palm male flowers; porous carbon; cobalt phosphide; deoxygenation; green diesel; bio-jet fuel

\section{Introduction}

Nowadays, the depletion of petroleum due to the annual acceleration of energy consumption has become a worldwide agenda, and created a necessity for the exploration of renewable and sustainable fuels and chemicals [1]. In recent decades, bioresources such as lignocellulosic materials, organic wastes, and plant oils, have been utilized as feedstocks for the production of renewable biofuel and bio-based chemicals, providing some levels of the global reduction of $\mathrm{CO}_{2}$ greenhouse gas. Many approaches have been proposed to efficiently convert plant oils into biofuels. Among them, transportation biofuels in the form of liquid hydrocarbons could be produced via catalytic deoxygenation reaction (DO) through the main reaction routes including hydrodeoxygenation (HDO) and decarboxylation/decarbonylation $\left(\mathrm{DeCO}_{\mathrm{x}}\right)$, with $\mathrm{H}_{2} \mathrm{O}$ and $\mathrm{CO}_{2} / \mathrm{CO}$ as by-products, respectively [2,3]. 
In DO reactions, catalysts are usually prepared by a method consisting of a metal on high surface area materials, which also play an important role in the reaction. Several porous support materials including carbons (e.g., active carbon, carbon nanotube) [4,5], zeolites (e.g., HY, HZSM-5, HZSM-22) [6] and mesoporous $\mathrm{SiO}_{2}$ (e.g., MCM-41, SBA-15) $[7,8]$ have been explored to study their effects on the catalytic performance. The catalyst supports having high acidity, such as zeolites which would promote deoxygenation activity as well as isomerization/cracking. In the literature, the acidic sites are important in catalyzing $\mathrm{C}-\mathrm{O}$ and $\mathrm{C}-\mathrm{C}$ bond cleavages, and also in increasing the selectivity of HDO products $[9,10]$. However, high acidic supports have been noted to cause the catalyst deactivation via coking or carbon deposition due to product condensation (a coke precursor). Additionally, high acidity also causes the cracking reaction of alkanes leading to a decrease in long-chain hydrocarbons selectivity from deoxygenation process $[9,10]$. Thus, the use of mild acid supports, such as porous carbons, $\mathrm{TiO}_{2}$, and $\mathrm{ZrO}_{2}$ are more beneficial to avoid the effect of support material. Nonetheless, a crucial property of catalyst supports is their high surface area. Many researchers have investigated the use of porous carbons such as biochar [11,12], activated carbons prepared from biomass [4], and carbon nanotubes $[6,13]$ as a support for metal catalysts in DO. Previous studies suggested that porous carbons are one of the most suitable and effective supports for deoxygenation catalysts $[4,6,13,14]$, because of their large surface area, which allows the dispersion of the metal catalyst. Porous carbons also have good mechanical stability under high temperature and pressure. Guo and co-workers [15] prepared activated carbon (AC)-supported Ni- and Co phosphide catalysts and tested their HDO activities for pyrolysis oil upgrading. They claimed that AC is the best support materials to enhance $\mathrm{HDO} /$ hydrogenation performance in bio-oil upgrading. Asikin-Mijan et al. studied the effects of $\mathrm{Ni}$ and Co on multi-wall carbon nanotubes for the hydrotreatment of jathopha curcas oil [16]. Furthermore, Larissa and co-workers reported that a high surface area of porous carbons over a thousand $\mathrm{m}^{2} / \mathrm{g}$ could be obtained using a $5 \mathrm{wt} \% \mathrm{Pd} / \mathrm{AC}$ catalyst $\left(1068 \mathrm{~m}^{2} / \mathrm{g}\right)$ [17].

Traditionally, a metal sulfide such as $\mathrm{MoS}_{2}$ [18], CoMo-S [19], and NiMo-S [20] catalysts on alumina and zeolite supports have been widely used in bio-hydrotreated fuel production. However, the leaching of toxic sulfiding agents causes serious environmental problems and is harmful to living organisms. This is due to the formation of undesirable S-containing biofuel products generated during the reaction $[1,18]$. The sulfur contamination must be reduced to meet the Euro emission standards, hence, requiring a complex unit operation. Supported metal catalysts without sulfur components such as metals and metal oxides have become more attractive for DO. Nevertheless, high acidic support can swiftly deposit coke and shorten the catalyst life-time, which makes these catalysts less effective [21]. Supported noble metal catalysts such as $\mathrm{Ru}, \mathrm{Rh}$, and $\mathrm{Pd}$ [22] which exhibit excellent $\mathrm{DO}$ activity, are promising. Nonetheless, the main limitation of noble metals is their high price, making them unattractive for industrial applications [22]. Thus, the investigation of low cost and highly active catalysts for biofuel production is needed.

Other active forms of catalysts such as transition metal phosphides have been employed for hydrodesulfurization and hydrodenitrogenation in petroleum refinery, due to its inexpensiveness, high stability, and excellent catalytic activity. These catalysts could be used for the hydrodechlorination of chlorobenzene in gas phase catalysis. Furthermore, they are stable in water and their electronic structures are quite similar to those of noble metals [23,24]. It is found that phosphorus species in metal phosphide catalysts enhance catalyst dispersion, acidity, coking resistance, mechanical strength and reactivity in hydrodeoxygenation [25]. Recent studies demonstrated using transition metal phosphide catalysts for the DO of various edible, non-edible oils, and model compounds. For instances, nickel-, iron-, and molybdenum phosphide catalysts are widely studied in the deoxygenation of methyl laurate [26], methyl palmitate [27], methyl oleate [28], and soybean oil [29]. Note that supported cobalt phosphides were rarely reported for the conversion of plant-based oils. Recently, Consuelo Alvarez-Galvan [30] studied the hydrotreatment of methyl laurate over metal phosphide catalysts, and found that the catalytic activity was in the order of $\mathrm{MoP}>\mathrm{CoP}>\mathrm{NiP}>\mathrm{FeP}$. They suggested that MoP favored the hydrodeoxygenation (HDO) pathway while $\mathrm{CoP}, \mathrm{NiP}$, and $\mathrm{FeP}$ were selective to 
decarboxylation/decarbonylation (DCOx). Hui et al. [31] prepared activated carbon-supported nickel phosphide catalysts via wet impregnation and tested them on the deoxygenation of palmitic acid for high-grade diesel production. They claimed that NiP supported on activated carbons offered the highest oil production yield of $56 \mathrm{wt} \%$. Moreover, the main products were $\mathrm{C}_{15}$, and the minor ones were $\mathrm{C}_{11}-\mathrm{C}_{14}$ alkanes and alkenes. They indicated that NiP favored deoxygenation through the DCOx pathway, which required lower $\mathrm{H}_{2}$ consumption.

As described above, cobalt phosphide is one of the promising catalysts for deoxygenation due to its high activity and selectivity of deoxygenation products. However, very few studies investigated the use of cobalt phosphide catalysts in the deoxygenation of vegetable oils for biofuel production. Hence, this study aims at using cobalt phosphide (CoP) catalysts for palm oil conversion to bio-hydrocarbons. In this process, porous carbon derived from palm male flowers (PMFs) using microwave-assisted potassium hydroxide $(\mathrm{KOH})$ activation, was employed as a catalyst support. The PMF was an abundant and low-cost agricultural waste. The approach to use wastes from palm industry as a major component in the catalytic materials for the production of palm-based biofuels offers an alternative concept in biorefinery. Consequently, the performance of the developed catalysts for producing bio-based diesel and jet fuels was presented and discussed. The selectivity to each biofuel product can be successfully controlled by tuning the catalyst properties and reaction conditions.

\section{Materials and Methods}

\subsection{Materials}

Palm male flowers (PMFS), also known as dried flowers, were collected from a local plantation in the southern part of Thailand for the preparation of porous carbon. Raw PMFs were dried at $105^{\circ} \mathrm{C}$ in a hot-air oven until the samples were completely dried and stored for further experiments. Cobalt (II) nitrate hexahydrate $\left(\mathrm{Co}\left(\mathrm{NO}_{3}\right)_{2}{ }^{\bullet} 6 \mathrm{H}_{2} \mathrm{O}, 98 \%\right.$ purity), potassium hydroxide $(\mathrm{KOH})$, phosphoric acid $\left(\mathrm{H}_{3} \mathrm{PO}_{4}\right)$, and hydrochloric acid $(\mathrm{HCl})$ were purchased from CARLO ERBA Reagents Co., Ltd., Paris, France. A high purity (99.99\%) nitrogen was obtained from Praxair, Co., Ltd. A palm oil feedstock (palm olein) was commercially obtained from a local market in Thailand. The fatty acid composition of the palm oil is as follows: lauric acid (C12:0) $0.4 \%$; myristic acid (C14:0) $0.8 \%$; palmitic acid (C16:0) 37.4\%; palmitoleic acid (C16:1) $0.2 \%$; steraric acid (C18:0) 3.6\%; oleic acid (C18:1) 45.8\%; linoleic acid (C18:2) 11.1\%; linolemic acid (18:3) 0.3\%; arachidic acid(C20:0) 0.3\%; and eicosenoic acid (C20:1) 0.1\%.

\subsection{Synthesis of Cobalt Phosphide@PC Catalysts}

The PMF porous carbon (PC) was prepared by a microwave-assisted activation method using $\mathrm{KOH}$ as an activating agent. Raw PMFs were pre-carbonized at $500{ }^{\circ} \mathrm{C}$ under nitrogen with a flow rate of $100 \mathrm{~mL} / \mathrm{min}$ [32]. The carbonized PMFs were physically mixed with $\mathrm{KOH}$ with a ratio of PMF char: $\mathrm{KOH}$ ratios at $2.0(w / w)$. The ground mixture was placed in a quartz crucible followed by activation in a custom-made microwave pyrolyzer (Samsung MS23F301EAW) with a frequency of $2.45 \mathrm{GHz}$. The activation was performed at a microwave power of $700 \mathrm{~W}$ using a constant radiation time period of 6 min [33]. Afterwards, the PCs were passivated at room temperature under $\mathrm{N}_{2}$ atmosphere, and then washed with $0.5 \mathrm{M} \mathrm{HCl}$ and deionized water several times until a neutral $\mathrm{pH}$ was obtained. The washed PCs were dried at $105{ }^{\circ} \mathrm{C}$ overnight before being crushed and sieved to obtain PCs of $0.18-0.5 \mathrm{~mm}$ in size. The PC sample prepared at the optimum condition was selected as a support for the preparation of the cobalt phosphide catalysts.

Series of cobalt phosphide supported on PC were synthesized by a wet impregnation method using cobalt (II) nitrate hexahydrate $\left(\mathrm{Co}\left(\mathrm{NO}_{3}\right)_{2}{ }^{\bullet} 6 \mathrm{H}_{2} \mathrm{O}\right)$ with a controlled metal loading of $10 \mathrm{wt} \%$ and a phosphorus content following the initial 1.0 molar ratio of $\mathrm{Co} / \mathrm{P}$. In the typical preparation, $\mathrm{Co}\left(\mathrm{NO}_{3}\right)_{2} \cdot 6 \mathrm{H}_{2} \mathrm{O}$ was dissolved and stirred in the deionized water, then conc. $\mathrm{H}_{3} \mathrm{PO}_{4}$ was added dropwise to the solution followed by the addition of the PC powders. The mixture was kept at $80^{\circ} \mathrm{C}$ for $3 \mathrm{~h}$. The impregnated sample was then pyrolyzed under a $\mathrm{N}_{2}$ flow of $100 \mathrm{~mL} / \mathrm{min}$ for $2 \mathrm{~h}$ with a 
ramping rate of $5{ }^{\circ} \mathrm{C} / \mathrm{min}$ in a tubular furnace at various temperatures from 600 to $900{ }^{\circ} \mathrm{C}$ to obtain the supported $\mathrm{Co}-\mathrm{O}-\mathrm{P}$ polyphosphate complex species. Before further characterization and the catalytic testing, the pyrolyzed samples (cobalt phosphate) were converted into cobalt phosphides by reduction under $\mathrm{H}_{2}$ atmosphere.

\subsection{Catalytic Deoxygenation of the Palm Olein Oil}

The deoxygenation of the palm olein oil over the as-synthesized cobalt phosphide supported on PC was carried out in a down-flow trickle-bed reactor having an internal tube dimension of $7 \mathrm{~mm}$ in diameter and $700 \mathrm{~mm}$ long. Prior to the reaction test, $8 \mathrm{~mL}(2.5 \mathrm{~g})$ of granular catalyst with sizes of $150-450 \mu \mathrm{m}$ was loaded into the middle zone of the reactor. The catalyst was subsequently "in situ" reduced under a $\mathrm{H}_{2}$ atmosphere with a $50 \mathrm{~mL} / \mathrm{min}$ (99.99\% purity, Praxair Co., Ltd., Bangkok, Thailand) at $600{ }^{\circ} \mathrm{C}$ for $3 \mathrm{~h}$. Then, the reactor was cooled down to the target reaction temperature $\left(340-420^{\circ} \mathrm{C}\right)$ and was pressurized with $\mathrm{H}_{2}$ to 50 bar controlled by a back pressure regulator. In deoxygenation, the palm oil was continuously fed by a HPLC pump at a varied liquid hourly space velocity (LHSV) of $0.5-1.5 \mathrm{~h}^{-1}$ under the use of a $\mathrm{H}_{2} /$ liquid ratio of $1000 \mathrm{~N}\left(\mathrm{~cm}^{3} / \mathrm{cm}^{3}\right)$. The start-up time was at $4 \mathrm{~h}$ when the system was in a steady-state condition. Each experiment entry was done on fresh catalysts in order to eliminate the effect of catalyst deactivation that might occur after each experiment. The liquid product was periodically collected at every $2 \mathrm{~h}$ intervals for analysis. The gas products $\left(\mathrm{C}_{3} \mathrm{H}_{8}\right.$, $\mathrm{C}_{2} \mathrm{H}_{6}, \mathrm{CH}_{4}, \mathrm{CO}, \mathrm{CO}_{2}$ ) were analyzed by online-gas chromatography (GC) equipped with a thermal conductivity detector (TCD) and a flame ionization detector (FID) (GC-2010 Plus, Shimadzu) and using Rt-Alumina BOND/KCL, Porapak Q, and MS-13X analytical columns. The liquid product compositions were analyzed by an offline gas chromatography equipped with a mass spectrometer detector (GCMS-QP2020, Shimadzu, Japan) and a capillary column (DB-1HT, $30 \mathrm{~m} \times 0.32 \mathrm{~mm} \times 0.1 \mu \mathrm{m}$ ). The conversion of oil feed was defined as a mass of triglyceride change into others (intermediates and hydrocarbons). The product yields were determined based on the mass balance of liquid hydrocarbon in the products corresponding to the oil feed. The conversion of palm oil, liquid hydrocarbon (LHC) yield, selectivity to green diesel $\left(\mathrm{C}_{15}-\mathrm{C}_{18}\right)$ and bio-jet $\left(\mathrm{C}_{9}-\mathrm{C}_{14}\right.$ hydrocarbon) were calculated using the following equations:

$$
\begin{gathered}
\text { Conversion of palm oil }(\%)=\frac{\text { Mass of oil in feed }- \text { Mass of oil in product }}{\text { Mass of oil in feed }} \times 100 \\
\text { Liquid hydrocarbons (LHCs) yield }(\%)=\frac{\text { Mass of LHCs in product }}{\text { Mass of oil in feed }} \times 100 \\
\text { Selectivity to green diesel }(\%)=\frac{\text { Mass of green diesel in product }}{\text { Mass of oil converted }} \times 100 \\
\text { Selectivity to bio }- \text { jet }(\%)=\frac{\text { Mass of bio }- \text { jet in product }}{\text { Mass of oil converted }} \times 100
\end{gathered}
$$

\subsection{Characterization of PC and PC-Supported Cobalt Phosphide Catalysts}

Proximate analysis was used to determine the chemical composition, including the moisture, volatile substances, fixed carbon and ash [34]. The moisture content, which was the mass of water in samples, was determined by drying process according to an American Society for Testing Materials, ASTM D2867-99 method (ASTM, 2014) [35]. Volatile substances, which were organic contents in the sample that could be released during the heating process, were measured under an inert atmosphere according to an ASTM D5832-98 (ASTM, 2008) [34,36]. Ash, which was referred to an inorganic component in the carbon structure, was analyzed by direct combustion according to an ASTM D2866-94 (ASTM, 2011) [34,36]. A non-volatile carbon remaining in the sample referred to as fixed carbon was calculated by subtracting techniques [34,36]. Ultimate analysis by CHN elemental analyzer (Leco truespec $\mathrm{CHN}-628$ ) was used to determine the elemental compositions of raw PMF and 
as-prepared porous carbon (i.e., carbon, hydrogen, oxygen and nitrogen). The oxygen percentage was directly calculated by subtraction from other elemental compositions in the ultimate analysis. All the analyses are shown in an as-received basis.

The porosity and pore structure of the as-received PCs and CoP/PC catalysts were determined by nitrogen adsorption-desorption isotherm analysis at $-196{ }^{\circ} \mathrm{C}$ using a gas sorption analyzer (Quantachrome Autosorp iQ-MP-XR). The Brunauer-Emmett-Teller (BET) model was used for the determination of the BET surface area $\left(\mathrm{S}_{\mathrm{BET}}\right)$. The pore size distribution was analyzed by using the density functional theory (DFT) model, while the micropore volume $\left(\mathrm{V}_{\mathrm{mic}}\right)$ was determined by the $\mathrm{t}$-plot model. The total pore volume $\left(\mathrm{V}_{\mathrm{T}}\right)$ was evaluated by a condensation of liquid nitrogen at the relative pressure of 0.99 . The mesopore volume $\left(\mathrm{V}_{\text {mes }}\right)$ was calculated by subtracting the micropore volume from the total pore volume [32].

The surface functional group characteristics of the PMF, PC, and CoP/PC catalysts were studied using the Fourier transform infrared spectroscopy, FTIR (Perkin Elmer UATR Two). The infrared absorption spectra were measured in transmission mode with a wavenumber range from $4000-500 \mathrm{~cm}^{-1}$ [32]. The samples were put into infrared platform and screw-impressed directly before performing the FTIR data collection. X-ray diffractograms of all the catalysts were achieved using $\mathrm{Cu}-\mathrm{K} \alpha$ radiation generated at $40 \mathrm{kV}$ and $40 \mathrm{~mA}$, in steps of $0.01^{\circ} \mathrm{S}^{-1}$ with a step time of $0.5 \mathrm{~s}$ over the range of $5^{\circ}<2 \theta<90^{\circ}$ on an X-ray diffractometer, XRD (SmartLab, Rigaku, Japan). The crystalline size of the catalysts was calculated from the XRD data using the Debye-Scherrer formula.

The morphology of the PC and CoP/PC catalysts were examined by a scanning electron microscope, SEM (Zeiss EVO50) operating at $20 \mathrm{kV}$ and a transmission electron microscope, TEM (JEOL JEM-2100plus) equipped with an energy dispersive $\mathrm{X}$-ray spectrometer (EDS). $\mathrm{NH}_{3}$-temperature programmed desorption (TPD) was carried out using Quantachrome Chemisorption Analyzer ChemStar TPX Series, equipped with a thermal conductivity detector using $5 \% \mathrm{NH}_{3} / \mathrm{He}$ as a probe gas.

\section{Results and Discussion}

\subsection{Physicochemical Characteristics of PC}

The proximate and ultimate analysis (elemental compositions; $\mathrm{C}, \mathrm{H}, \mathrm{N}$ ) of the raw PMF, carbonized PMF and PMF-derived porous carbon (PC) are shown in Table 1. A high $\mathrm{C}$ percentage is determined from both carbon atoms of the fixed carbon and volatile matters in the porous carbon structure. The observed small amount of $\mathrm{N}$ content could be from a native component of plant-based materials such as enzymes or protein, and remains chemisorbed nitrogen in the carbon structure during carbonization [30,34]. The PMF, carbonized PMF and PC have an N content lower than 1.3\% (0.9-1.2\%). Typically, the $\mathrm{H}$ element was chemically bonded with carbon atoms; however, the ratio of $\mathrm{H}$ to $\mathrm{C}$ may be influenced by moisture. The composition of PMF has the lowest $C$ content about $43.7 \%$ since it has a high $O$ content $(52.6 \%)$ in the form of oxygenated compounds and the moisture of lignocellulosic biomass [37]. Furthermore, the $\mathrm{C}$ content increases after the pre-carbonization step, as measured in the carbonized PMF (68.7\%) due to the devolatilization. The PC produced in this study contains a high C content of about $79.1 \%$, which is quite similar to the conventional porous carbon consisting of $80-90 \%$ C [38].

Table 1. Proximate and ultimate analysis of the palm male flower (PMF), carbonized PMF and the PMF porous carbon (PC).

\begin{tabular}{cccccccccc}
\hline \multirow{2}{*}{ Conditions } & \multicolumn{3}{c}{ Proximate Analysis (As-Received Basis, $w / w)$} & \multicolumn{4}{c}{ Ultimate Analysis (As-Received Basis, $w / w)$} \\
\cline { 2 - 10 } & $\mathbf{M}$ & VM & FC & A & C & H & N & O \\
\hline PMF & 7.6 & 61.1 & 24.0 & 7.3 & 43.7 & 2.4 & 1.2 & 52.6 \\
\hline Carbonized PMF & 2.1 & 26.7 & 64.4 & 6.6 & 68.7 & 1.3 & 0.9 & 29.1 \\
\hline PC 700W (s) & 2.9 & 13.7 & 74.6 & 8.9 & 79.1 & 0.9 & 0.9 \\
\hline
\end{tabular}

M: moisture, VM: volatile matter, FC: fixed carbon, A: ash., (s) utilized as support materials for the preparation of the cobalt phosphide catalysts. 
The proximate analysis, represented in Table 1, provides the gross composition of the biomass in four parameters, namely moisture, fixed carbon, volatile matter, and ash. The fixed carbon represents the non-volatile carbon matters, which are the major component in the porous carbon structure, while ash reflects the persistent component (typically inorganic matters) found in the biomass. For instance, the pores can be blocked when the porous carbon contains a high ash content, leading to the lower BET surface area [39]. The BET surface area of the obtained PC is approximately $964.0 \mathrm{~m}^{2} / \mathrm{g}$ with total pore volume $\left(\mathrm{V}_{\mathrm{T}}\right)$ of $0.57 \mathrm{~cm}^{3} / \mathrm{g}$, as demonstrated in Table 2. The pore structure of the PC is commonly identified by using $\mathrm{N}_{2}$ adsorption-desorption technique [34]. As shown in Figure 1a, the PC sample displays a mixed characteristic of Type I and Type IV isotherms, classified by IUPAC, which exhibit a specific combination of microporous and mesopores structures $[40,41]$.

Table 2. Pore characteristics of PMF porous carbon (PC) and CoP/PC catalysts.

\begin{tabular}{|c|c|c|c|c|c|c|}
\hline \multirow{2}{*}{ Conditions } & \multicolumn{4}{|c|}{ Pore Characteristics } & \multirow{2}{*}{$\mathrm{D}_{\mathrm{XRD}}(\mathrm{nm})$} & \multirow{2}{*}{$\begin{array}{c}\mathrm{NH}_{3} \text { Uptake } \\
\quad(\mu \mathrm{mol} / \mathrm{g})\end{array}$} \\
\hline & $S_{\text {BET }}\left(\mathrm{m}^{2} / \mathrm{g}\right)$ & $\mathrm{V}_{\mathrm{T}}\left(\mathrm{cm}^{3} / \mathrm{g}\right)$ & $\mathrm{V}_{\text {mic }}(\%)$ & $\mathrm{V}_{\text {mes }}(\%)$ & & \\
\hline PC 700W (s) & 964.0 & 0.57 & 77.92 & 22.08 & - & - \\
\hline CoP/PC-600 & 822.9 & 0.43 & 68.79 & 31.21 & 3.4 & 52.5 \\
\hline CoP/PC-700 & 750.5 & 0.35 & 66.85 & 33.15 & 11.7 & 85.2 \\
\hline CoP/PC-800 & 629.2 & 0.31 & 62.06 & 37.94 & 26.8 & 113.2 \\
\hline CoP/PC-900 & 578.2 & 0.29 & 59.72 & 40.28 & 21.7 & 118.1 \\
\hline
\end{tabular}

(s) Utilized as support materials for the preparation of the cobalt phosphide catalysts.
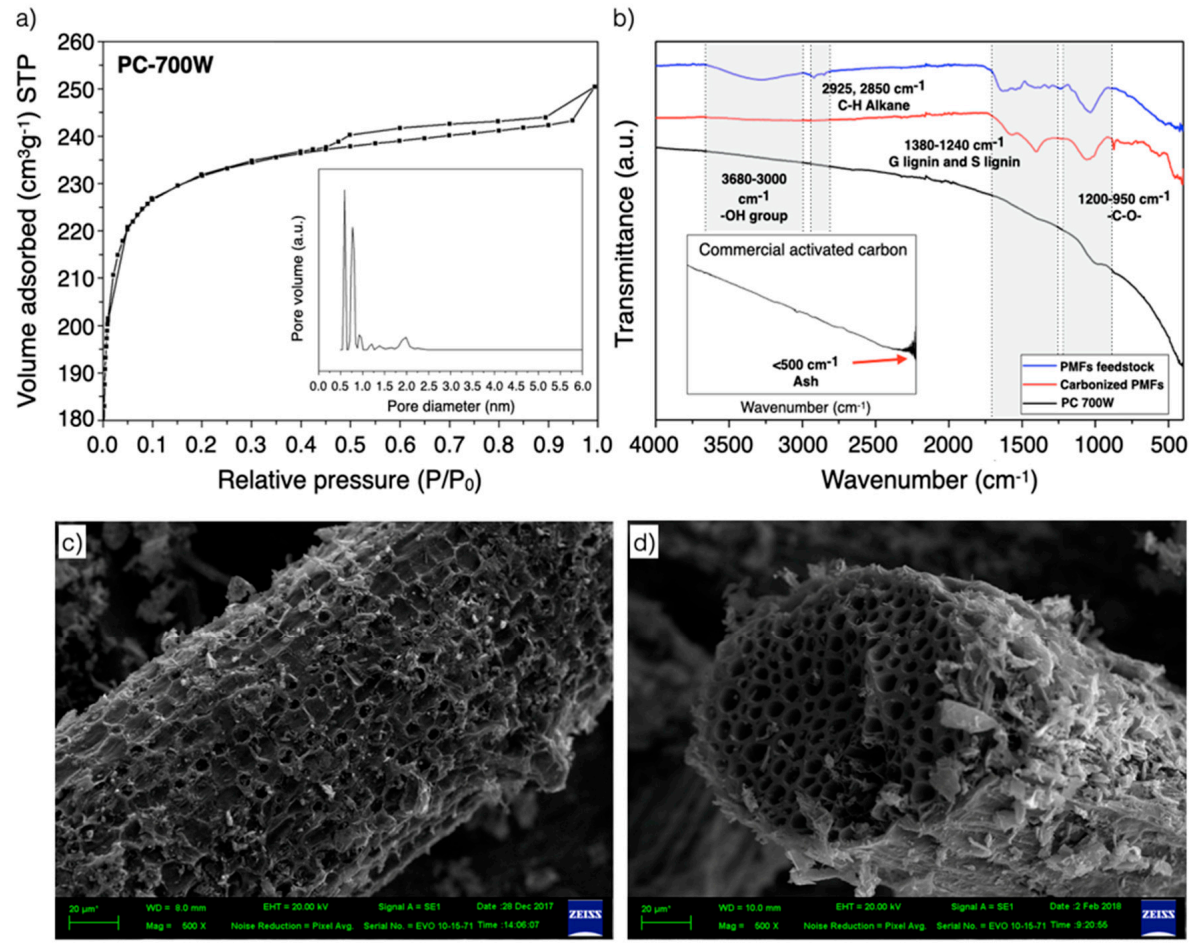

Figure 1. Characterization of the PMF porous carbon (PC) prepared at the microwave radiation power of $700 \mathrm{~W}$; (a) the $\mathrm{N}_{2}$ adsorption-desorption isotherms; (b) the FTIR analyses of the PMF, carbonized PMF and the PMF porous carbon (PC); (c) the SEM micrograph of the external surface; and (d) the cross-section SEM micrograph.

The surface chemistry of PC was evaluated by using FTIR. The FTIR spectra of the PMF, carbonized PMF, and the PC were compared to that of the commercial activated carbon. In Figure $1 b$, the band in the $3680-3000 \mathrm{~cm}^{-1}$ region is related to $-\mathrm{OH}$ stretching indicating the characteristic of hydroxyl and carbonyl functional groups of lignin in lignocellulosic biomass, as expected from PMF feedstock. 
The vibrations at about 2925 and $2850 \mathrm{~cm}^{-1}$ correspond to the aliphatic C-H stretching assigned to the polysaccharide of cellulose and hemicellulose. Moreover, aromatic $-\mathrm{C}=\mathrm{C}-$ stretching of lignin is mainly observed between 1600 and $1512 \mathrm{~cm}^{-1}$. Other bands of lignin also situate at 1380-1240 $\mathrm{cm}^{-1}$ and $1460 \mathrm{~cm}^{-1}$. The $\mathrm{C}=\mathrm{O}$ vibrations assigned for cellulose and hemicellulose are observed from 1200 to $950 \mathrm{~cm}^{-1}$. On the contrary, the spectra below $500 \mathrm{~cm}^{-1}$ can be ascribed to the vibration of inorganic components [42]. The absence of vibration bands in the $3680-2850 \mathrm{~cm}^{-1}$ region in the PMF and PC samples are due to the decomposition of lignocellulosic components during carbonization and microwave activation [43]. Additionally, the activation power of $700 \mathrm{~W}$ seems to successfully convert PMF into porous carbon, with the surface characteristic as similar as the commercial activated carbon (shown in the inset graph of Figure 1b), confirmed by the resemblance of their FTIR spectra across the measured region. Furthermore, the SEM micrographs of the PC are shown in Figure 1c for the external surface and Figure $1 \mathrm{~d}$ for the cross-sectional view. The external surface of the PC shows various external small pore cavities. Moreover, various cavities can be observed inside the external pores-like spongy matrix, which is displayed in the cross-section SEM image (Figure 1d). The surface and pore structures of the PC signify its good potential as a catalyst support.

\subsection{Characterization of CoP/PC Catalysts}

$\mathrm{CoP} / \mathrm{PC}$ catalysts were synthesized by the wet impregnation technique using an initial $\mathrm{P} / \mathrm{Co}$ of 1.0 molar ratio using $\mathrm{H}_{3} \mathrm{PO}_{4}$ with the controlled $10 \%$ metal loading, followed by the pyrolysis of impregnated samples (phosphate species), and the $\mathrm{H}_{2}$ reduction of phosphate species into cobalt phosphide, respectively. The effect of the pyrolysis temperatures of impregnated samples before the reduction process was investigated on the phase formation of cobalt phosphides and their reactivity in palm olein oil deoxygenation. In order to examine the mentioned $\mathrm{CoP} / \mathrm{PC}$ catalysts regarding the specific properties, a series of $\mathrm{CoP} / \mathrm{PC}$ catalysts were characterized.

In Figure 2a, the FTIR spectra of all CoP/PC catalysts were observed with a weak peak intensity between 635 and $535 \mathrm{~cm}^{-1}$, corresponding to the phosphate vibrations in the CoP catalysts [44], whereas this feature is absent in the FTIR spectrum of the bare PC support. These results confirm that the cobalt phosphide phase was observed on the PC support at the different pyrolysis temperatures from $600^{\circ} \mathrm{C}$ to $900^{\circ} \mathrm{C}$. Varying temperatures in the pyrolysis of the impregnated samples, which are totally amorphous, reveal an influence on transformation of $\mathrm{CoP}$ crystalline structure in the corresponding activated catalysts (after the reduction process), as displayed in Figure $2 b$. The observed XRD broad peak around $40^{\circ}-50^{\circ}$ represents the overlapping peaks between the carbon support and the characteristic of an amorphous and well dispersed cobalt phosphide phase on carbon support, in a reduced catalyst obtained by pyrolysis at $600^{\circ} \mathrm{C}$. On the other hand, the sharp and high intensity peaks were found when the pyrolysis temperature further increased before reduction. Typically, the diffraction peaks at $40.8^{\circ}, 43.4^{\circ}, 44.2^{\circ}$ and $52.1^{\circ}$ were observed, corresponding to the diffraction peaks of the (121), (211), (130), and (002) planes of $\mathrm{Co}_{2} \mathrm{P}$ (JCPDS-32-0306) [45]. Besides, the diffraction peaks at $35.3^{\circ}$, $36.5^{\circ}, 46.2^{\circ}, 48.3^{\circ}, 52.2^{\circ}$, and $56.4^{\circ}$ can be attributed to the (200), (102), (112), (202), (103), and (212) crystal planes of $\mathrm{CoP}$ (JCPDS-20-0497) [45]. The strong peaks of the $\mathrm{Co}_{2} \mathrm{P}$ phase were found at $700{ }^{\circ} \mathrm{C}$ while the $\mathrm{Co}_{2} \mathrm{P}$ was also transformed into a $\mathrm{CoP}$ species when increasing the pyrolysis temperature to $800{ }^{\circ} \mathrm{C}$ and higher. This was evidenced by the observed mixture of highly crystalline $\mathrm{Co}_{2} \mathrm{P}$ and $\mathrm{CoP}$ phases at 800 and $900{ }^{\circ} \mathrm{C}$ of the reduced catalysts. In addition, the CoP species is significantly formed at a high temperature that requires high-phase formation energy. According to these results, it was noted that the pyrolysis temperature before the reduction process was a key factor in the formation of cobalt phosphides in the reduced catalysts and increasing the pyrolysis temperature during catalyst preparation results in the transformation from $\mathrm{Co}_{2} \mathrm{P}$ to $\mathrm{CoP}$ crystalline structures. As shown in Table 2, the crystallite size of the cobalt phosphide in the reduced catalysts was calculated by the Debye-Scherrer equation $\left(D_{\text {xrd }}\right)$. The cobalt phosphide crystallite sizes are significantly enlarged from 3.4 to $21.7 \mathrm{~nm}$ by raising the pyrolysis temperature from 600 to $900{ }^{\circ} \mathrm{C}$. 
a)
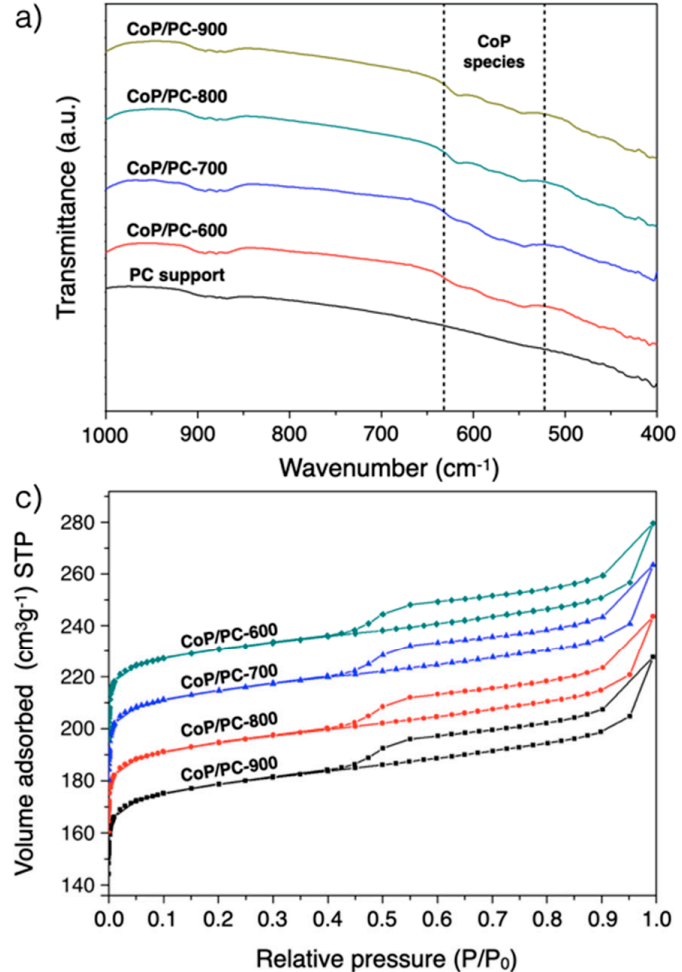

b)

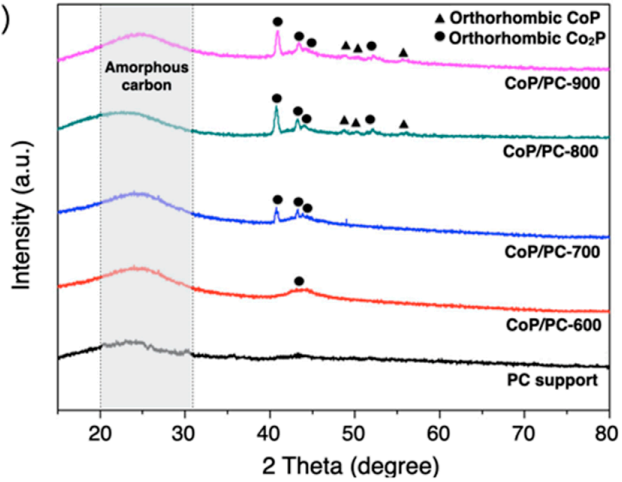

d)

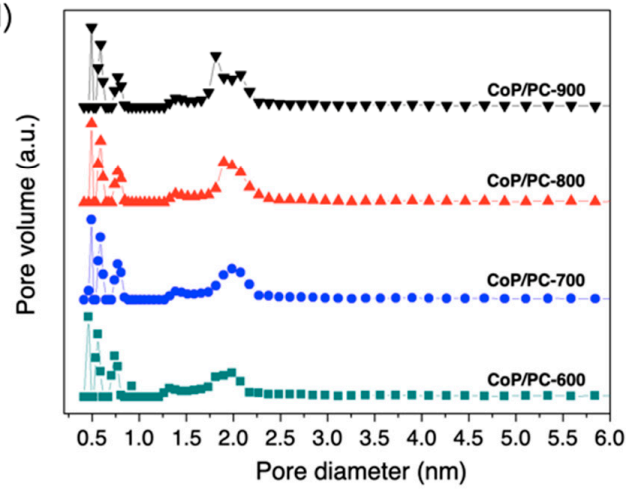

Figure 2. Characterization of the reduced $\mathrm{CoP} / \mathrm{PC}$ catalysts prepared using various pyrolysis temperatures between 600 and $900{ }^{\circ} \mathrm{C}$; (a) the FTIR analyses; (b) the XRD patterns; (c) the $\mathrm{N}_{2}$ adsorption-desorption isotherm; and (d) the pore size distribution.

Figure 2c displays the $\mathrm{N}_{2}$ adsorption-desorption isotherms of the reduced CoP/PC catalysts, prepared using different pyrolysis temperatures. All the isotherms show the typical Type I isotherm combined with the type IV isotherm with a narrow hysteresis loop at the high relative pressure. These results suggest that micropores with a mesopores formation exist in the samples, and the isotherm data were derived to calculate porous parameters, as shown in Table 2. An increase in the pyrolysis temperature leads to the shifting of the isotherm toward the lower volume of the adsorbed $\mathrm{N}_{2}$, suggesting a decreasing surface area of catalysts [46]. Furthermore, the decrease in the surface area of catalysts might be affected by the mean particle size of the CoP catalyst due to the aggregation at high-temperature pyrolysis [47]. The pore size distribution (PSD) analysis of the obtained catalysts was evaluated by the DFT model (Figure 2d). The PSD of the samples could be separated into two main distribution ranges within $4 \mathrm{~nm}$. The catalysts have narrow micropores with the existence of sharp peaks between 0.5 and $1.0 \mathrm{~nm}$, while the PSD around $1.3 \mathrm{~nm}$ is also observed with a smaller density. The tiny mesopores of narrow PSD are in the range of around $2.0-2.5 \mathrm{~nm}$. The increasing pyrolysis temperature before the reduction in the catalyst preparation significantly shifts and elevates the mesopore size distribution because of the collapse of micropores.

The acidity of the reduced catalysts was also measured using $\mathrm{NH}_{3}-\mathrm{TPD}$. The total $\mathrm{NH}_{3}$ uptakes range from 52.5 to $118.1 \mu \mathrm{mol} / \mathrm{g}$, as reported in Table 2. The catalyst with a high crystalline CoP phase (CoP/PC-900) has much larger $\mathrm{NH}_{3}$ uptake than those of the other catalysts. The lowest acidity is found in the $\mathrm{CoP} / \mathrm{PC}-600$ with the main phase of $\mathrm{Co}_{2} \mathrm{P}$. However, a recent study $[10,34]$ found that the highly acidic catalyst presents an excellent deoxygenation activity since the cleavage of $\mathrm{C}-\mathrm{C}$ is favorably catalyzed by the acid sites of catalysts. Moreover, the hydrocracking of heavy hydrocarbons to light molecules is extremely promoted in the similar contribution [42].

TEM images and the particle size distribution curves of the reduced catalysts prepared with various pyrolysis temperatures before the $\mathrm{H}_{2}$ reduction are shown in Figure 3: (a) $600{ }^{\circ} \mathrm{C}$, (b) $700{ }^{\circ} \mathrm{C}$, (c) $800{ }^{\circ} \mathrm{C}$, and (d) $900^{\circ} \mathrm{C}$. All the catalysts exhibit a good dispersion of the cobalt phosphide particles 
on the PC support. The cobalt phosphide particle size become larger with the increasing pyrolysis temperature before the activation into the active phase by $\mathrm{H}_{2}$ reduction, due to the aggregation of metal salt particles on carbon support. The average particle sizes of cobalt phosphide are enlarged from $15.8 \mathrm{~nm}\left(\right.$ at $600{ }^{\circ} \mathrm{C}$ ) to 31.2 (at $900{ }^{\circ} \mathrm{C}$ ). In addition, the particle size distribution of the CoP catalysts was investigated with the accuracy of $\pm 1 \mathrm{~nm}$. All the samples show the similar trends of narrow size distribution within 10-20 nm, suggesting the well-controlled size distribution via the present synthesis method. The TEM image of the reduced CoP/PC-600 catalyst with EDS mapping (Figure 4) confirms the elemental composition of the catalyst. The corresponding EDS mapping of the elemental results reveals a successful cobalt phosphide loading on the carbon support, and the uniform dispersion of CoP crystals surrounded by a carbon framework.
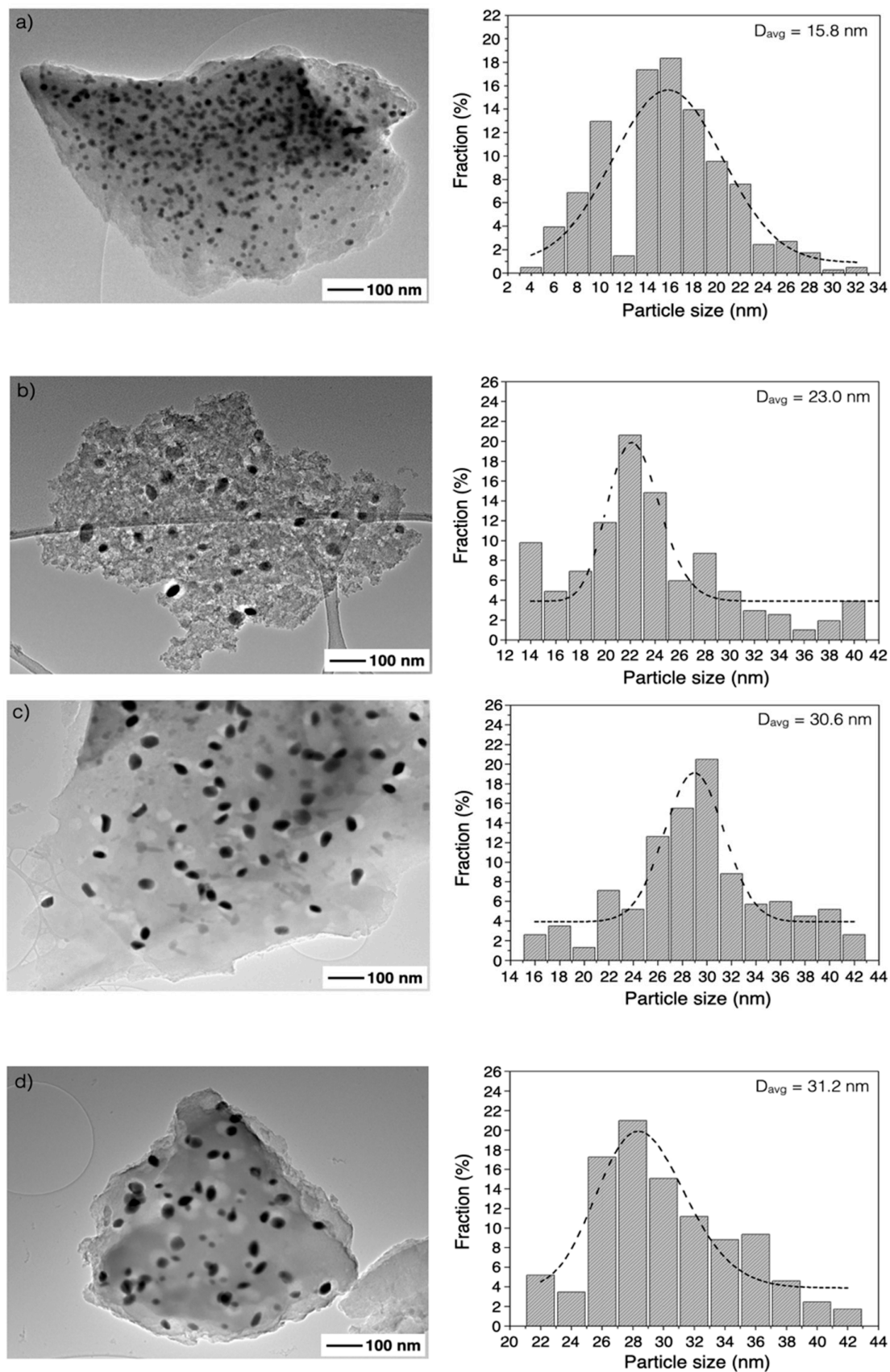

Figure 3. Observation of the reduced CoP/PC catalysts by the TEM analysis and the particle size distribution prepared at the different pyrolysis temperatures of (a) 600; (b) 700; (c) 800; and (d) $900{ }^{\circ} \mathrm{C}$. 
a)

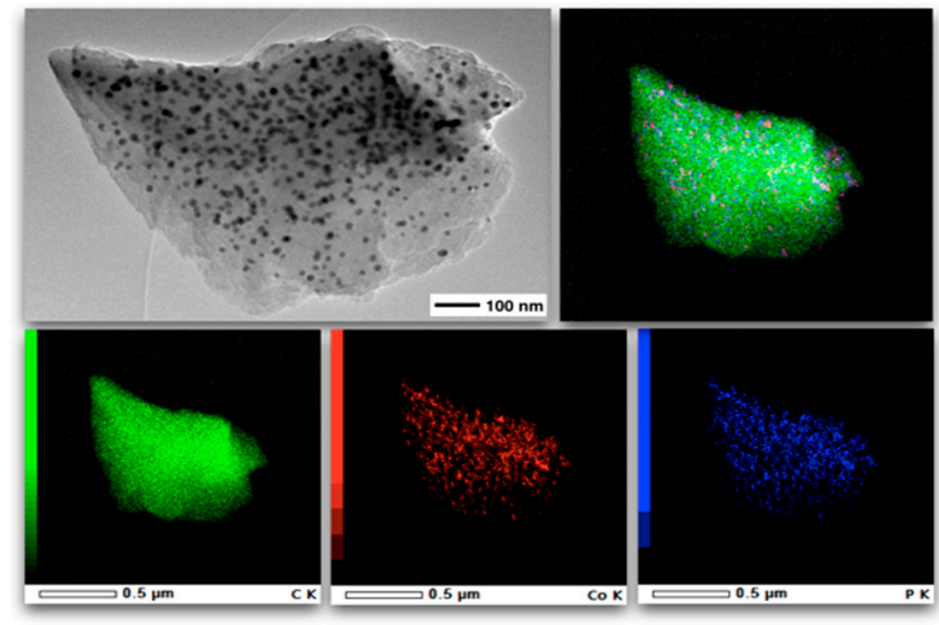

b)

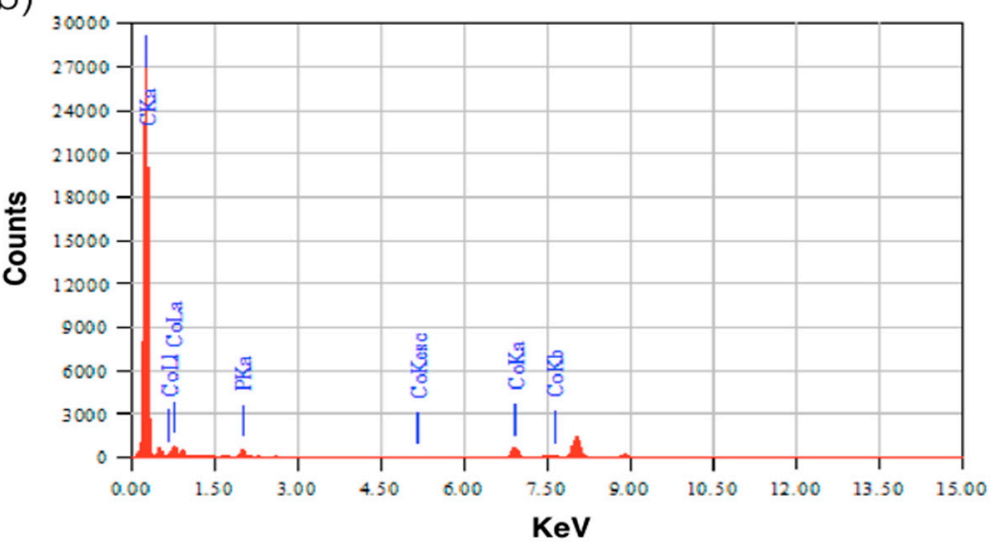

Figure 4. (a) TEM image of the CoP/PC-600 catalyst and the EDS mapping of the C, Co, and P elements; and $(\mathbf{b})$ the corresponding EDS spectrum.

\subsection{Palm oil Deoxygenation over CoP/PC Catalysts}

\subsubsection{Effects of Cobalt Phosphide Species on Palm Oil Deoxygenation Performance}

The palm oil deoxygenation performance was impacted by the cobalt phosphide species, which was obtained from different pyrolysis temperatures during the catalyst preparation before the reduction process. The temperatures in the pyrolysis of impregnated samples determine the stoichiometry of the cobalt phosphide catalysts. This also affects the catalytic behavior of the corresponding catalysts. In this work, the effect of the pyrolysis temperatures during the catalyst preparation on the conversion and the product yield with \% selectivity of liquid hydrocarbons were conducted in the wide temperature ranges from 600 to $900{ }^{\circ} \mathrm{C}$ under a fixed operating condition as follows: reaction temperature: $400{ }^{\circ} \mathrm{C}$; $\mathrm{H}_{2}$ pressure: 50 bar; and $\mathrm{H}_{2} / \mathrm{Oil}$ ratio: $1000 \mathrm{~N}\left(\mathrm{~cm}^{3} / \mathrm{cm}^{3}\right)$. Figure 5 a shows the impacts of the pyrolysis temperature during the catalyst preparation on the palm olein oil conversion and the liquid hydrocarbon yield. All the catalysts achieved the $100 \%$ conversion, however, the catalysts obtained at a higher temperature from 600 to $900{ }^{\circ} \mathrm{C}$ slightly decreased the liquid hydrocarbons yield from 75.9 to $71.0 \%$. In Figure 5b, the green diesel selectivity gradually decreased from 45.2 to $35.1 \%$, while the bio-jet selectivity became greater when raising the pyrolysis temperature of the catalysts, perhaps due to the more catalytic hydrocracking presented in the samples with a higher total acidity e.g., the CoP/PC-800 and CoP/PC-900 catalysts (Table 2). It should be noted that at the higher reaction temperature, the high cracking reactivity typically leads to the decrease in liquid hydrocarbon yield 
and green diesel selectivity, whereas yields of shorter-carbon chain molecules including biojet and gas products are enhanced.

a)

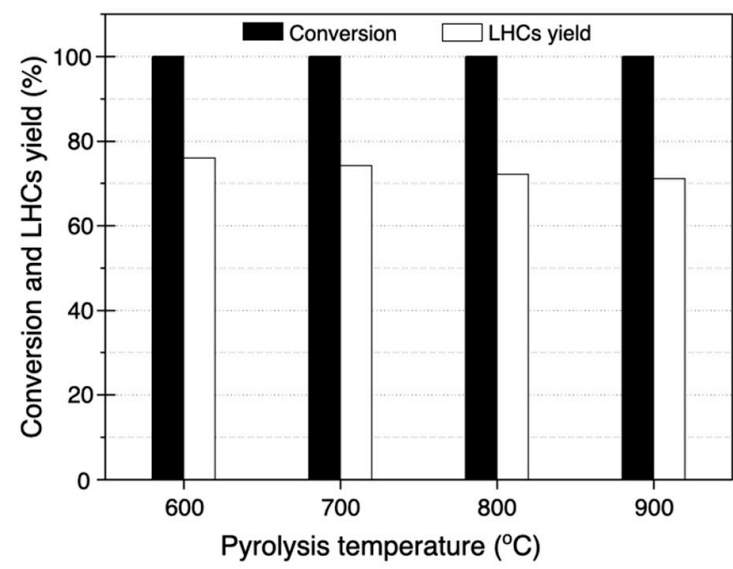

c)

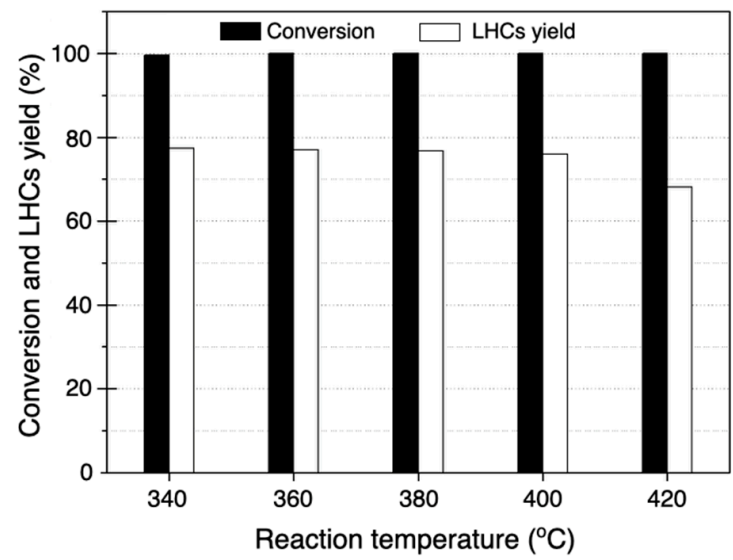

e)

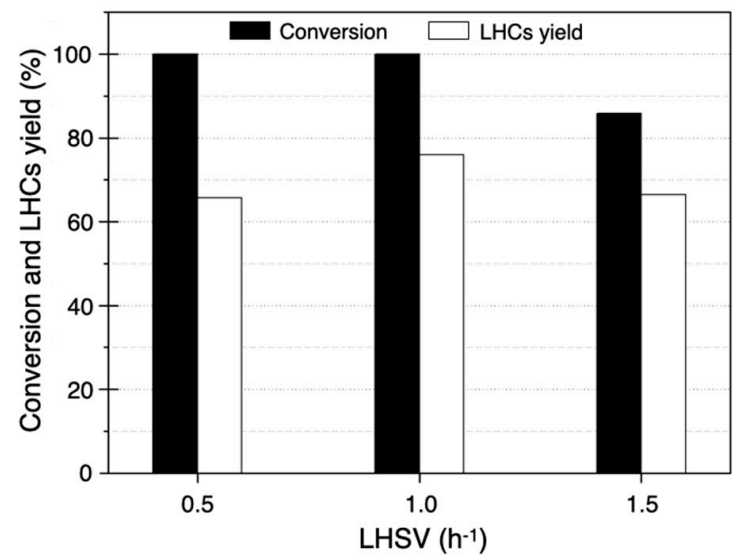

b)

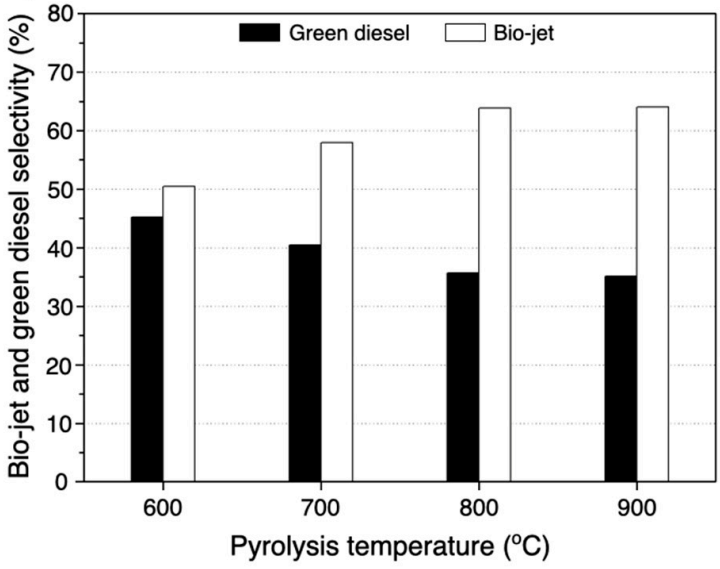

d)

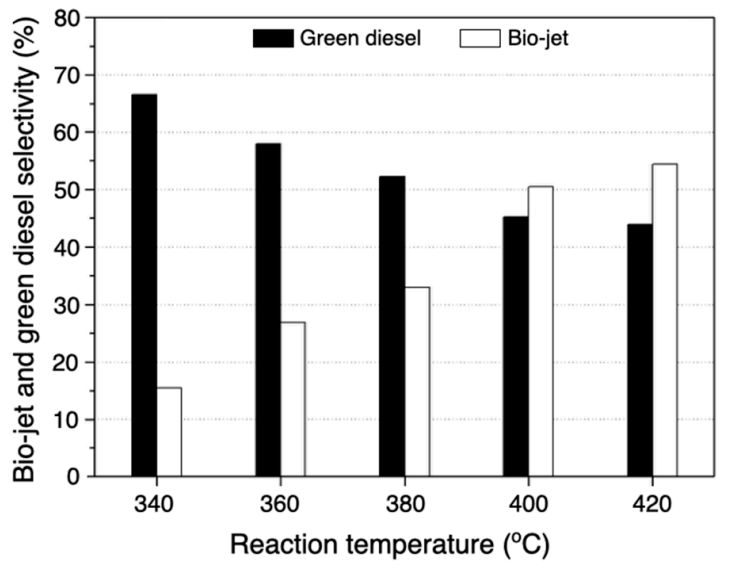

f)

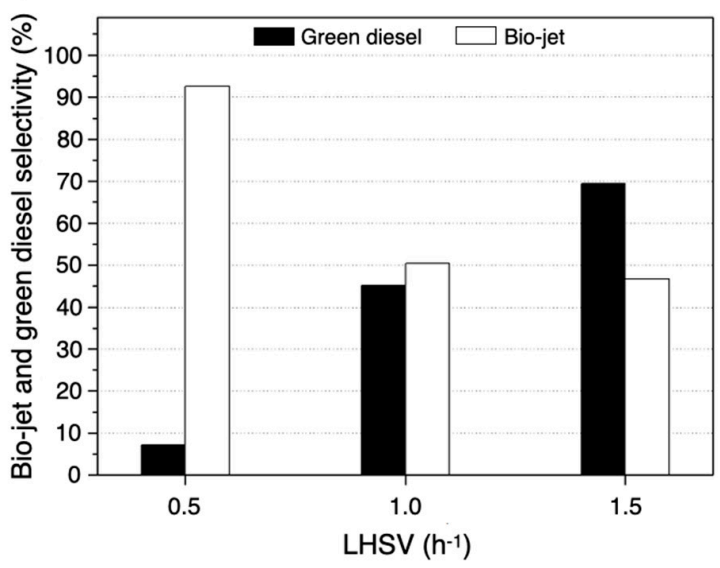

Figure 5. Effects of the pyrolysis temperatures before the reduction process of the CoP/PC catalysts $(\mathbf{a}, \mathbf{b})$, the deoxygenation reaction (DO) reaction temperatures $(\mathbf{c}, \mathbf{d})$ and the liquid hourly space velocities (LHSVs) (e,f) on the palm oil conversion, liquid hydrocarbon yield, and the selectivity to green diesel $\left(\mathrm{C}_{15}-\mathrm{C}_{18}\right)$ and bio-jet $\left(\mathrm{C}_{9}-\mathrm{C}_{14}\right)$.

According to the $\mathrm{XRD}$ results, at the low pyrolysis temperature during the catalyst preparation before the $\mathrm{H}_{2}$ reduction to phosphide, $\mathrm{Co}_{2} \mathrm{P}$ was firstly formed, and then followed by the formation of $\mathrm{CoP}$ with an increasing synthesis temperature corresponding to the sufficient energy of phase 
transformation $[44,46]$. It is noted that the $\mathrm{CoP}$ and $\mathrm{Co}_{2} \mathrm{P}$ phases would show different activity in deoxygenation. A recent study revealed that the cobalt phosphide catalysts prepared at the high pyrolysis temperature of phosphate salt on carbon supports, presented a high proportion of CoP phases [45,46], which was considered to be an active form of cobalt phosphide and exhibited a higher catalytic performance [24]. The performance of cobalt phosphide catalysts is directly related to the $\mathrm{P} / \mathrm{Co}$ ratio in the cobalt phosphide structure leading to a type of cobalt phosphide phase present on the catalyst surface. These results explain the initial activity for these series catalysts [24]. In this sense, the rich $\mathrm{P} / \mathrm{Co}$ ratio in the $\mathrm{CoP}$ phase would exhibit a greater amount of hydrogen spillover effect than the $\mathrm{Co}_{2} \mathrm{P}$ one, resulting in a higher activity.

The CoP/PC-600 catalyst was selected for the further study of the DO parameters including the DO temperatures and the LHSV, since the use of the CoP/PC-600 catalyst can achieve $100 \%$ palm oil conversion and the highest liquid hydrocarbon yield while the well dispersed nanosized cobalt phosphide particles are achieved (as shown in Figure 3a). Moreover, a lower preparation temperature could be beneficial in terms of energy consumption and investment cost for the equipment installation and operation.

\subsubsection{Effects of DO Temperatures}

The effect of deoxygenation temperatures $\left(340-420^{\circ} \mathrm{C}\right)$ over the CoP/PC-600 was investigated. It is found that the palm oil deoxygenation over the $\mathrm{CoP} / \mathrm{PC}$ catalyst has a complete conversion in the temperature range of $340-420^{\circ} \mathrm{C}$ (Figure $5 \mathrm{c}$ ). The product yield kept quite constant in the reaction temperature range from 340 to $380^{\circ} \mathrm{C}$, but dropped at a temperature above $400{ }^{\circ} \mathrm{C}$, suggesting the promotion of cracking activity. Abdulkareem Alsultan [13] and Asikin-Mijan [16] reported that the lower conversion was typically achieved at a lower deoxygenation temperature, which was not found in our study. As illustrated in Figure $5 d$, the selectivity of the liquid hydrocarbon products is varied with raising the reaction temperature from 340 to $420{ }^{\circ} \mathrm{C}$. The product in the green diesel range $\left(C_{15}-C_{18}\right.$ hydrocarbons) continuously declines, whereas the fraction of the bio-jet $\left(C_{9}-C_{14}\right.$ hydrocarbons) tends to increase since the cracking reaction is favorable at a higher temperature to convert longer-chain hydrocarbons into shorter-chain hydrocarbons $[48,49]$.

\subsubsection{Effects of Liquid Hourly Space Velocity (LHSV)}

The LHSV is one of the most important variables in the continuous flow trickle bed reactor system to evaluate catalyst effectiveness, the expected catalyst life time, and the reaction behavior [10]. Previous studies noted that the formation of white waxy oxygenated intermediates, mainly free fatty acids and long-chain esters, are observed at high operating LHSV leading to rapid blockage inside the reactor. Moreover, the low LHSV (long resident time) plays an important role for the isomerization and cracking reaction in the deoxygenation of triglyceride feedstock $[29,30]$. In this section, the influences of LHSVs on the conversion and product yield with a \% selectivity of products were conducted at various LHSV of $0.5,1.0$, and $1.5 \mathrm{~h}^{-1}$ under a fixed operating condition as follows: reaction temperature of $400{ }^{\circ} \mathrm{C} ; \mathrm{H}_{2}$ Pressure of 50 bar; and $\mathrm{H}_{2} / \mathrm{Oil}$ ratio: $1000 \mathrm{~N}\left(\mathrm{~cm}^{3} / \mathrm{cm}^{3}\right)$ using CoP/PCs-600 catalyst. As displayed in Figure $5 \mathrm{e}$, the LHSVs of 0.5 and $1.0 \mathrm{~h}^{-1}$ obtained $100 \%$ conversion at a deoxygenation temperature of $400^{\circ} \mathrm{C}$ without waxy compounds. Nonetheless, an increase in LHSV from 1.0 to $1.5 \mathrm{~h}^{-1}$ gradually decreases the conversion of triglycerides to $85.9 \%$, which is influenced by the lowering contact time between the oxygenated compound and the catalyst surface. Patil et al. [50] reported that high space velocity rapidly plugged the reactor with waxy oxygenated compounds, mainly composed of free fatty acids and esters. Moreover, the increase in LHSV might slightly decrease the hydrocarbon yield, indicating the insufficient contact time of reactants and catalysts. The liquid hydrocarbon yield of low LHSV $\left(0.5 \mathrm{~h}^{-1}\right)$ was approximately $65.7 \mathrm{wt} \%$ and the highest selectivity of bio-jet $(92.6 \%)$ was obtained because the thermal/catalytic cracking and isomerization reactions simply occurred at the long contact time. The highest liquid hydrocarbon yields $(75.9 \mathrm{wt} \%)$ were obtained at a moderate LHSV $\left(1.0 \mathrm{~h}^{-1}\right)$ with the balance of bio-jet and green diesel fractions of 50.4 and $45.2 \%$, respectively, 
as shown in Figure 5f. On the other hand, the high LHSV drops the liquid hydrocarbon yield to $66.4 \mathrm{wt}$ $\%$ (corresponding to the lower conversion) with the highest green diesel selectivity of $69.3 \%$. However, in terms of the product composition yields, it was revealed that the increase in contact time (at a low LHSV) would generate more gas products obtained by simultaneous cracking reaction [51]. Therefore, a lesser amount of gas products is obtained at a low LHSV and an uncompleted conversion results in the formation of oxygenated compounds in the liquid product.

As shown in Figure 6, the by-products of the deoxygenation of palm oil consisting of water and $C_{1}-C_{3}$ gas products are significantly influenced by various experimental parameters. These are also suggested by a previous report [48]. In general, free fatty acids, the main oxygenated compounds, could be converted into hydrocarbons via several routes in the deoxygenation process. As displayed in Figure 6a, the elimination of water from palm oil is about $4.0-7.3 \mathrm{wt} \%$ of the total liquid products, mainly through hydrodeoxygenation and also a small proportion from decarbonylation. In this study, the effects of DO temperature and LHSV were tested on a CoP/PC-600 catalyst under a $\mathrm{H}_{2}$ pressure of 50 bar and a $\mathrm{H}_{2} / \mathrm{Oil}$ ratio of $1000 \mathrm{~N}\left(\mathrm{~cm}^{3} / \mathrm{cm}^{3}\right)$. Our results show that increasing the DO reaction temperature and lowering the LHSV reduced the water fraction. The decrease in the water fraction is correlated with the lesser selectivity of the hydrodeoxygenation and decarbonylation pathways under the studied operating conditions, evidenced by the lessened $\mathrm{CO}$ amount due to the water-gas-shift reaction [52] which proceeds as a side reaction. In addition, the effects of increasing pyrolysis temperature on catalyst activity were tested on a fixed operating condition: the reaction temperature of $400{ }^{\circ} \mathrm{C}$, an $\mathrm{H}_{2}$ pressure of $50 \mathrm{bar}$, and an $\mathrm{H}_{2} /$ Oil ratio of $1000 \mathrm{~N}\left(\mathrm{~cm}^{3} / \mathrm{cm}^{3}\right)$. Regarding the XRD analysis, increasing the pyrolysis temperature could transform the $\mathrm{Co}_{2} \mathrm{P}$ to $\mathrm{CoP}$. The $\mathrm{CoP}$ phase was considered more active than the $\mathrm{Co}_{2} \mathrm{P}$ phase. The $\mathrm{CoP} / \mathrm{PC}$ catalysts obtained at the higher pyrolysis temperature typically gave lower water content in the liquid products.

a)
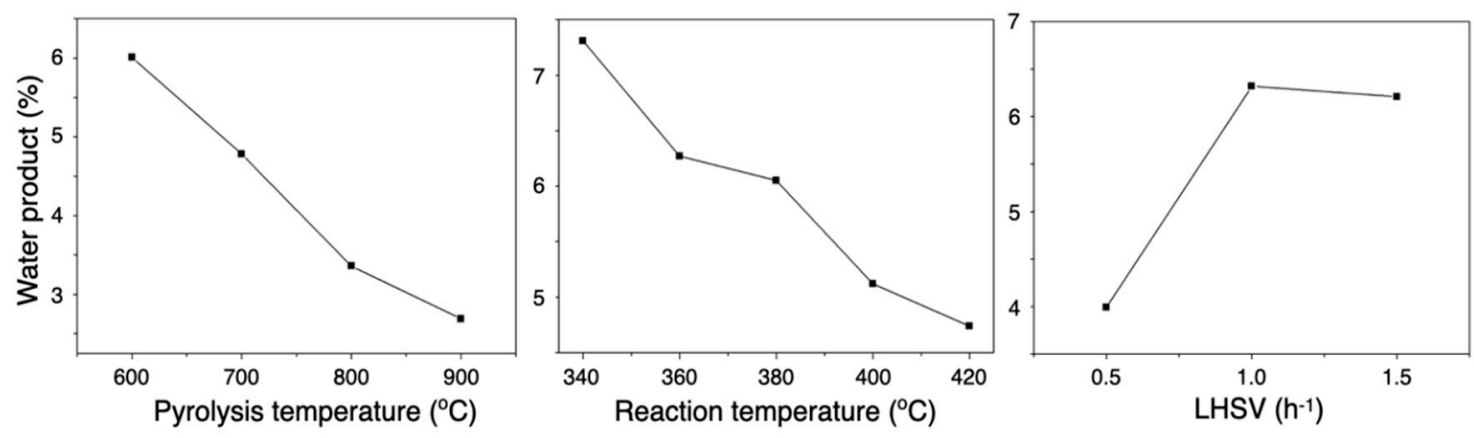

b)
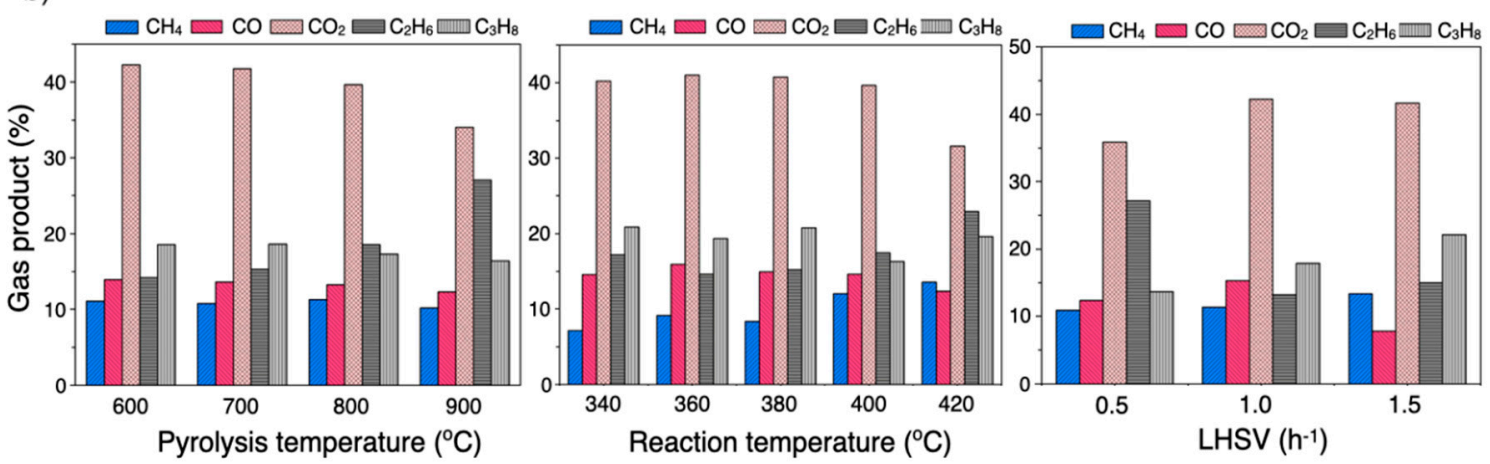

Figure 6. Effect of the operating variables on (a) the water composition in the liquid products and (b) the gas composition (excluding $\mathrm{H}_{2}$ ) in the gas products during the palm oil deoxygenation under a 50 bar of $\mathrm{H}_{2}$ pressure and $\mathrm{H}_{2}$ : Feed ratio of $1000 \mathrm{~N}\left(\mathrm{~cm}^{3} / \mathrm{cm}^{3}\right)$. The reduced CoP/PC-600 catalyst was used to study the effect of the reaction temperature and LSHV. 
A major gas fraction was released from the decarbonylation/decarboxylation reactions in the form of $\mathrm{CO} / \mathrm{CO}_{2}$, as shown in Figure $6 \mathrm{~b}$. Furthermore, the $\mathrm{C}_{3} \mathrm{H}_{8}$ gas was produced from the hydrogenolysis of saturated triglycerides. However, gas products could be generated from the cracking reaction under the harsh DO condition resulting in light hydrocarbon formation such as $\mathrm{CH}_{4}, \mathrm{C}_{2} \mathrm{H}_{6}, \mathrm{C}_{3} \mathrm{H}_{8}$, as suggested by Pinto et al. [53]. The slight decrease in $\mathrm{C}_{3} \mathrm{H}_{8}$ would be describable to its cracking to $\mathrm{CH}_{4}$ and $\mathrm{C}_{2} \mathrm{H}_{6}$. Perhaps, the increase in the amount of $\mathrm{CH}_{4}$ also relates to the decrease in $\mathrm{CO}$ and $\mathrm{CO}_{2}$ via methanation with $\mathrm{H}_{2}$ [10,53]. It is worth noting that the gas products also contained small amounts of light hydrocarbons, $\mathrm{C}_{4}-\mathrm{C}_{7}(<2.6 \%)$ which were likely formed via the cracking reaction of bio-jet products $[48,49]$. According to Figure $6 \mathrm{~b}$, the findings suggest that the DO temperature, the LHSV and the pyrolysis temperature during the catalyst preparation significantly influenced the composition of the by-products of palm oil deoxygenation. Moreover, the CoP phase, which shows a higher acidity than $\mathrm{Co}_{2} \mathrm{P}$, can favorably promote catalytic hydrocracking under the high DO temperature condition i.e., $400{ }^{\circ} \mathrm{C}$ or higher. In addition, the comparison of the catalytic hydrotreatment with the different catalysts and the different conditions for biofuel production from various fatty acid feedstocks is shown in Table 3. Some non-precious metal catalysts, such as $\mathrm{MoO}_{2} / \mathrm{CNTs}, \mathrm{Ni} / \mathrm{H}-\mathrm{ZSM}-22$, and $\mathrm{Ni}-\mathrm{Co} / \mathrm{MWCNTs}$, were successfully used for the production of green diesel biofuels in a batch-type reactor. In addition, the use of $\mathrm{NiP}$ catalysts such as $\mathrm{NiP} / \mathrm{SiO}_{2}$ and $\mathrm{NiP} / \mathrm{AC}$ was demonstrated for the conversion of soybean oil and palmitic acid into green diesel, respectively. The present work shows for the first time the use of a CoP catalyst with the carbon support derived from the biomass waste which is highly cost effective. Moreover, we show that the carbon-supported cobalt phosphide catalyst was effective in producing both the diesel-range and jet-range biofuels. The CoP/AC developed in this work can be considered a promising catalyst for advanced biofuel production.

Table 3. Amount of biofuel production from the catalytic hydrotreatment with different catalysts and different conditions.

\begin{tabular}{|c|c|c|c|c|c|}
\hline Catalyst & Reagent & Condition & $\begin{array}{c}\text { Conversion } \\
(\%)\end{array}$ & Product & Reference \\
\hline $\mathrm{MoO}_{2} / \mathrm{CNTs}$ & $\begin{array}{l}\text { Palmitic } \\
\text { acid }\end{array}$ & $\begin{array}{c}190-260{ }^{\circ} \mathrm{C} 40 \text { bar, } 300 \mathrm{rpm} \\
\text { (batch reactor) }\end{array}$ & $53.8-100$ & $\begin{array}{c}\text { Diesel-like } \\
\text { hydrocarbons }\end{array}$ & [4] \\
\hline Ni/H-ZSM-22 & $\begin{array}{l}\text { Palmitic } \\
\text { acid }\end{array}$ & $\begin{array}{c}150-260{ }^{\circ} \mathrm{C} 40 \text { bar, } 300 \mathrm{rpm} \\
\text { (batch reactor) }\end{array}$ & $72.2-100$ & Green diesel & [6] \\
\hline $\mathrm{Ni}-\mathrm{Co} / \mathrm{MWCNTs}$ & $\begin{array}{l}\text { Jatropha } \\
\text { curcas oil }\end{array}$ & $\begin{array}{c}350{ }^{\circ} \mathrm{C} 10 \text { bar, } 1 \mathrm{~h}, 400 \mathrm{rpm} \\
\text { (batch reactor) }\end{array}$ & 100 & Green diesel & [16] \\
\hline $\mathrm{NiP} / \mathrm{SiO}_{2}$ & Soybean oil & $\begin{array}{c}340-420{ }^{\circ} \mathrm{C}, 30 \mathrm{bar} \\
\mathrm{LHSV}=1 \mathrm{~h}^{-1} \\
\text { (continuous reactor) }\end{array}$ & 100 & Green diesel & [29] \\
\hline $\mathrm{NiP} / \mathrm{AC}$ & $\begin{array}{l}\text { Palmitic } \\
\text { acid }\end{array}$ & $\begin{array}{c}350{ }^{\circ} \mathrm{C} 1 \text { bar, } \\
\text { (continuous reactor) }\end{array}$ & $86.2-100$ & $\begin{array}{l}\text { High grade } \\
\text { diesel }\end{array}$ & [31] \\
\hline $\begin{array}{l}\text { CoP/Porous } \\
\text { carbon }\end{array}$ & $\begin{array}{l}\text { Palm olein } \\
\quad \text { oil }\end{array}$ & $\begin{array}{l}340-420{ }^{\circ} \mathrm{C}, 50 \mathrm{bar} \\
\mathrm{LHSV}=1 \mathrm{~h}^{-1} \\
\text { (continuous reactor) }\end{array}$ & 100 & $\begin{array}{l}\text { Bio-jet fuel, } \\
\text { Green diesel }\end{array}$ & This study \\
\hline
\end{tabular}

\section{Conclusions}

In this study, microwave-assisted activation is an effective process for porous carbon production due to the reduction in the operating time. Moreover, palm male flower-derived porous carbon (PC) exhibits a great potential as a carbon-based catalyst support. The results show that the cobalt phosphide supported on PC catalysts becomes an effective catalyst in the deoxygenation of vegetable oil or non-edible oil for the production of alternative transportation fuels. The characteristics of $\mathrm{CoP} / \mathrm{PC}$ catalysts strongly influence catalytic behaviors and the selectivity of hydrocarbon products. Pyrolysis temperature during catalyst preparation significantly controls the formation of the cobalt phosphide phase after the reduction process. At $800-900{ }^{\circ} \mathrm{C}$ pyrolysis temperature, mixed phases of 
cobalt phosphide compounds are generated. The $\mathrm{Co}_{2} \mathrm{P}$ formation firstly occurs and is later converted into $\mathrm{CoP}$ while the pyrolysis at $600-700{ }^{\circ} \mathrm{C}$ results in a lower yield of the single phase $\mathrm{Co}_{2} \mathrm{P}$. It is noted that $\mathrm{CoP}$ exhibits a higher hydrocracking activity than $\mathrm{Co}_{2} \mathrm{P}$, as suggested by the obtained product distribution in the deoxygenation of palm oil at $400{ }^{\circ} \mathrm{C}$. The important keys on the deoxygenation activity of cobalt phosphide catalysts are operating conditions such as temperature and LHSV. The $\mathrm{CoP} / \mathrm{PC}$ catalyst pyrolyzed at $600{ }^{\circ} \mathrm{C}$ exhibits a $100 \%$ triglyceride conversion at $360^{\circ} \mathrm{C}$ and the highest liquid hydrocarbons yield of $77.0 \%$ with a selectivity to bio-jet of $26.9 \%$ and a selectivity to green diesel of $58.0 \%$. The hydrocarbon yield decreases when the reaction temperature rises to $420{ }^{\circ} \mathrm{C}$ with a high fraction of bio-jet fuel. Furthermore, reducing the LHSV exhibits a lower liquid hydrocarbon yield with a high fraction of bio-jet fuel. The highest selectivity to bio-jet was achieved at $92.6 \%$ at an LHSV of $0.5 \mathrm{~h}^{-1}$. According to the findings, the improvements in the yield and selectivity of the desired liquid hydrocarbon products could be achieved by optimizing the operating parameters in deoxygenation and fine-tuning the acidity of cobalt phosphide/PC during the catalyst preparation.

Author Contributions: Conceptualization, N.K. and A.E.-U.; Methodology, N.K. and A.E.-U.; Software, N.K.; Validation, N.K., K.F. and A.E.-U.; Formal analysis, N.K., V.I., K.F. and A.E.; Investigation, N.K. and R.K.; Resources, N.K. and R.K.; Data curation, N.K.; Writing-original draft preparation, N.K.; Writing-review and editing, N.K., V.I. and K.F.; Visualization, N.K.; Supervision, K.F. and A.E.-U.; Project administration, K.F. and A.E.-U.; Funding acquisition, K.F. All authors have read and agreed to the published version of the manuscript.

Funding: The financial supports from the NANOTEC platform project (P1750381) and the CAS-NSTDA project (P1952712) are acknowledged. The authors also acknowledge the Thai Graduate Institute of Science and Technology Scholarship, TGIST (TG-55-22-60-011D) and College of Nanotechnology, King Mongkut's Institute of Technology Ladkrabang for their financial support.

Acknowledgments: The authors acknowledge Supapan Serapin, the NSTDA-RQM-Professional Authorship Center, for her technical support.

Conflicts of Interest: The funders had no role in the design of the study; in the collection, analyses, or interpretation of data; in the writing of the manuscript, or in the decision to publish the results.

\section{References}

1. Zhang, Y.; Bi, P.; Wang, J.; Jiang, P.; Wu, X.; Xue, H.; Liu, J.; Zhou, X.; Li, Q. Production of jet and diesel biofuels from renewable lignocellulosic biomass. Appl. Energy 2015, 150, 128-137. [CrossRef]

2. Ansari, K.B.; Gaikar, V.G. Investigating production of hydrocarbon rich bio-oil from grassy biomass using vacuum pyrolysis coupled with online deoxygenation of volatile products over metallic iron. Renew. Energy 2019, 130, 305-318. [CrossRef]

3. Veses, A.; Puértolas, B.; López, J.M.; Callén, M.S.; Solsona, B.; García, T. Promoting deoxygenation of bio-oil by metal-loaded hierarchical ZSM-5 zeolites. ACS Sustain. Chem. Eng. 2016, 4, 1653-1660. [CrossRef]

4. Ding, R.; Wu, Y.; Chen, Y.; Liang, J.; Liu, J.; Yang, M. Effective hydrodeoxygenation of palmitic acid to diesel-like hydrocarbons over $\mathrm{MoO}_{2} / \mathrm{CNTs}$ catalyst. Chem. Eng. Sci. 2015, 135, 517-525. [CrossRef]

5. Pham, L.K.H.; Tran, T.T.V.; Kongparakul, S.; Reubroycharoen, P.; Karnjanakom, S.; Guan, G.; Samart, C. Formation and activity of activated carbon supported Ni2P catalysts for atmospheric deoxygenation of waste cooking oil. Fuel Process. Technol. 2019, 185, 117-125. [CrossRef]

6. Cao, Y.; Shi, Y.; Liang, J.; Wu, Y.; Huang, S.; Wang, J.; Yang, M.; Hu, H. High iso-alkanes production from palmitic acid over bi-functional Ni/H-ZSM-22 catalysts. Chem. Eng. Sci. 2017, 158, 188-195. [CrossRef]

7. Cao, Y.; Shi, Y.; Bi, Y.; Wu, K.; Hu, S.; Wu, Y.; Huang, S. Hydrodeoxygenation and hydroisomerization of palmitic acid over bi-functional Co/H-ZSM-22 catalysts. Fuel Process. Technol. 2018, 172, 29-35. [CrossRef]

8. Kandel, K.; Anderegg, J.W.; Nelson, N.C.; Chaudhary, U.; Slowing, I.I. Supported iron nanoparticles for the hydrodeoxygenation of microalgal oil to green diesel. J. Catal. 2014, 314, 142-148. [CrossRef]

9. Bhattacharjee, S.; Tan, C.-S. Hydrodeoxygenation of oleic acid in hexane containing pressurized $\mathrm{CO}_{2}$ using Fe/SBA-15 as catalyst. J. Clean. Prod. 2017, 156, 203-213. [CrossRef]

10. Srifa, A.; Kaewmeesri, R.; Fang, C.; Itthibenchapong, V.; Faungnawakij, K. $\mathrm{NiAl}_{2} \mathrm{O}_{4}$ spinel-type catalysts for deoxygenation of palm oil to green diesel. Chem. Eng. J. 2018, 345, 107-113. [CrossRef] 
11. Han-u-domlarpyos, V.; Kuchonthara, P.; Reubroycharoen, P.; Hinchiranan, N. Quality improvement of oil palm shell-derived pyrolysis oil via catalytic deoxygenation over $\mathrm{NiMoS} / \gamma-\mathrm{Al}_{2} \mathrm{O}_{3}$. Fuel 2015, 143, 512-518. [CrossRef]

12. Li, H.; Qiu, Y.F.; Wang, X.L.; Yang, J.; Yu, Y.J.; Chen, Y.Q.; Liu, Y.D. Biochar supported Ni/Fe bimetallic nanoparticles to remove 1,1,1-trichloroethane under various reaction conditions. Chemosphere 2017, 169, 534-541. [CrossRef] [PubMed]

13. Alsultan, G.A.; Asikin-Mijan, N.; Lee, H.V.; Albazzaz, A.S.; Taufiq-Yap, Y.H. Deoxygenation of waste cooking to renewable diesel over walnut shell-derived nanorode activated carbon supported $\mathrm{CaO}-\mathrm{La}_{2} \mathrm{O}_{3}$ catalyst. Energy Convers. Manag. 2017, 151, 311-323. [CrossRef]

14. Duan, Y.; Ding, R.; Shi, Y.; Fang, X.; Hu, H.; Yang, M.; Wu, Y. Synthesis of renewable Diesel range alkanes by hydrodeoxygenation of palmitic acid over $5 \% \mathrm{Ni} / \mathrm{CNTs}$ under mild conditions. Catalysts 2017, 7, 81. [CrossRef]

15. Guo, C.; Rao, K.T.V.; Yuan, Z.; He, S.; Rohani, S.; Xu, C. Hydrodeoxygenation of fast pyrolysis oil with novel activated carbon-supported NiP and CoP catalysts. Chem. Eng. Sci. 2018, 178, 248-259. [CrossRef]

16. Asikin-Mijan, N.; Lee, H.V.; Abdulkareem-Alsultan, G.; Afandi, A.; Taufiq-Yap, Y.H. Production of green Diesel via cleaner catalytic deoxygenation of Jatropha curcas oil. J. Clean. Prod. 2017, 167, 1048-1059. [CrossRef]

17. Silva, L.N.; Fortes, I.C.P.; de Sousa, F.P.; Pasa, V.M.D. Biokerosene and green Diesel from macauba oils via catalytic deoxygenation over Pd/C. Fuel 2016, 164, 329-338. [CrossRef]

18. Grilc, M.; Veryasov, G.; Likozar, B.; Jesih, A.; Levec, J. Hydrodeoxygenation of solvolysed lignocellulosic biomass by unsupported $\mathrm{MoS}_{2}, \mathrm{MoO}_{2}, \mathrm{Mo}_{2} \mathrm{C}$ and WS2 catalysts. Appl. Catal. B Environ. 2015, 163, 467-477. [CrossRef]

19. Shim, J.-O.; Jeon, K.-W.; Jang, W.-J.; Na, H.-S.; Cho, J.-W.; Kim, H.-M.; Lee, Y.-L.; Jeong, D.-W.; Roh, H.-S.; $\mathrm{Ko}, \mathrm{C} . \mathrm{H}$. Facile production of biofuel via solvent-free deoxygenation of oleic acid using a CoMo catalyst. Appl. Catal. B Environ. 2018, 239, 644-653. [CrossRef]

20. Grilc, M.; Likozar, B.; Levec, J. Hydrodeoxygenation and hydrocracking of solvolysed lignocellulosic biomass by oxide, reduced and sulphide form of NiMo, Ni, Mo and Pd catalysts. Appl. Catal. B Environ. 2014, 150-151, 275-287. [CrossRef]

21. Wang, W.; Tan, S.; Zhu, G.; Wu, K.; Tan, L.; Li, Y.; Yang, Y. SDBS-assisted hydrothermal synthesis of flower-like Ni-Mo-S catalysts and their enhanced hydrodeoxygenation activity. RSC Adv. 2015, 5, 94040-94045. [CrossRef]

22. Diaz, E.; Mohedano, A.F.; Casas, J.A.; Rodriguez, J.J. Analysis of the deactivation of Pd, Pt and Rh on activated carbon catalysts in the hydrodechlorination of the MCPA herbicide. Appl. Catal. B Environ. 2016, 181, 429-435. [CrossRef]

23. Bjelić, A.; Grilc, M.; Huš, M.; Likozar, B. Hydrogenation and hydrodeoxygenation of aromatic lignin monomers over $\mathrm{Cu} / \mathrm{C}, \mathrm{Ni} / \mathrm{C}, \mathrm{Pd} / \mathrm{C}, \mathrm{Pt} / \mathrm{C}, \mathrm{Rh} / \mathrm{C}$ and $\mathrm{Ru} / \mathrm{C}$ catalysts: Mechanisms, reaction micro-kinetic modelling and quantitative structure-activity relationships. Chem. Eng. J. 2019, 359, 305-320. [CrossRef]

24. Cecilia, J.A.; Infantes-Molina, A.; Rodriguez-Castellon, E. Hydrodechlorination of polychlorinated molecules using transition metal phosphide catalysts. J. Hazard Mater. 2015, 296, 112-119. [CrossRef]

25. Griffin, M.B.; Baddour, F.G.; Habas, S.E.; Ruddy, D.A.; Schaidle, J.A. Evaluation of Silica-supported metal and metal phosphide nanoparticle catalysts for the hydrodeoxygenation of guaiacol under ex situ catalytic fast pyrolysis conditions. Top. Catal. 2015, 59, 124-137. [CrossRef]

26. Chen, J.; Shi, H.; Li, L.; Li, K. Deoxygenation of methyl laurate as a model compound to hydrocarbons on transition metal phosphide catalysts. Appl. Catal. B Environ. 2014, 144, 870-884. [CrossRef]

27. Guan, Q.; Wan, F.; Han, F.; Liu, Z.; Li, W. Hydrodeoxygenation of methyl palmitate over MCM-41 supported nickel phosphide catalysts. Catal. Today 2016, 259, 467-473. [CrossRef]

28. Yang, Y.; Ochoa-Hernández, C.; de la Peña O'Shea, V.A.; Coronado, J.M.; Serrano, D.P. Ni2P/SBA-15 as a hydrodeoxygenation catalyst with enhanced selectivity for the conversion of methyl oleate into n-octadecane. ACS Catal. 2012, 2, 592-598. [CrossRef]

29. Zarchin, R.; Rabaev, M.; Vidruk-Nehemya, R.; Landau, M.V.; Herskowitz, M. Hydroprocessing of soybean oil on nickel-phosphide supported catalysts. Fuel 2015, 139, 684-691. [CrossRef] 
30. Alvarez-Galvan, M.C.; Blanco-Brieva, G.; Capel-Sanchez, M.; Morales-delaRosa, S.; Campos-Martin, J.M.; Fierro, J.L.G. Metal phosphide catalysts for the hydrotreatment of non-edible vegetable oils. Catal. Today 2018, 302, 242-249. [CrossRef]

31. Xin, H.; Guo, K.; Li, D.; Yang, H.; Hu, C. Production of high-grade diesel from palmitic acid over activated carbon-supported nickel phosphide catalysts. Appl. Catal. B Environ. 2016, 187, 375-385. [CrossRef]

32. Foo, K.Y.; Hameed, B.H. Microwave-assisted preparation and adsorption performance of activated carbon from biodiesel industry solid reside: Influence of operational parameters. Bioresour. Technol. 2012, 103, 398-404. [CrossRef] [PubMed]

33. Moshood Abioye, A.; Ani, F.N. Advancement in the production of activated carbon from biomass using microwave heating. J. Teknol. 2017, 79, 79-88. [CrossRef]

34. Dizbay-Onat, M.; Vaidya, U.K.; Lungu, C.T. Preparation of industrial sisal fiber waste derived activated carbon by chemical activation and effects of carbonization parameters on surface characteristics. Ind. Crops Prod. 2017, 95, 583-590. [CrossRef]

35. Sayğılı, H.; Güzel, F. High surface area mesoporous activated carbon from tomato processing solid waste by zinc chloride activation: Process optimization, characterization and dyes adsorption. J. Clean. Prod. 2016, 113, 995-1004. [CrossRef]

36. Borchard, N.; Wolf, A.; Laabs, V.; Aeckersberg, R.; Scherer, H.W.; Moeller, A.; Amelung, W. Physical activation of biochar and its meaning for soil fertility and nutrient leaching-A greenhouse experiment. Soil Use Manag. 2012, 28, 177-184. [CrossRef]

37. Zhang, Y.-J.; Xing, Z.-J.; Duan, Z.-K.; Meng, L.; Wang, Y. Effects of steam activation on the pore structure and surface chemistry of activated carbon derived from bamboo waste. Appl. Surf. Sci. 2014, 315, 279-286. [CrossRef]

38. Marrakchi, F.; Ahmed, M.J.; Khanday, W.A.; Asif, M.; Hameed, B.H. Mesoporous-activated carbon prepared from chitosan flakes via single-step sodium hydroxide activation for the adsorption of methylene blue. Int. J. Biol. Macromol. 2017, 98, 233-239. [CrossRef]

39. Li, S.; Han, K.; Li, J.; Li, M.; Lu, C. Preparation and characterization of super activated carbon produced from gulfweed by KOH activation. Micropor. Mesopor. Mat. 2017, 243, 291-300. [CrossRef]

40. Choi, G.G.; Oh, S.J.; Lee, S.J.; Kim, J.S. Production of bio-based phenolic resin and activated carbon from bio-oil and biochar derived from fast pyrolysis of palm kernel shells. Bioresour. Technol. 2015, 178, 99-107. [CrossRef]

41. dos Reis, G.S.; Wilhelm, M.; Silva, T.C.d.A.; Rezwan, K.; Sampaio, C.H.; Lima, E.C.; de Souza, S.M.A.G.U. The use of design of experiments for the evaluation of the production of surface rich activated carbon from sewage sludge via microwave and conventional pyrolysis. Appl. Therm. Eng. 2016, 93, 590-597. [CrossRef]

42. Yang, X.; Ni, L. Synthesis of hybrid hydrogel of poly(AM co DADMAC)/silica sol and removal of methyl orange from aqueous solutions. Chem. Eng. J. 2012, 209, 194-200. [CrossRef]

43. Deng, H.; Li, G.; Yang, H.; Tang, J.; Tang, J. Preparation of activated carbons from cotton stalk by microwave assisted $\mathrm{KOH}$ and $\mathrm{K}_{2} \mathrm{CO}_{3}$ activation. Chem. Eng. J. 2010, 163, 373-381. [CrossRef]

44. Yao, Z.; Wang, G.; Shi, Y.; Zhao, Y.; Jiang, J.; Zhang, Y.; Wang, H. One-step synthesis of nickel and cobalt phosphide nanomaterials via decomposition of hexamethylenetetramine-containing precursors. Dalton Trans. 2015, 44, 14122-14129. [CrossRef] [PubMed]

45. Maneeprakorn, W.; Malik, M.A.; O'Brien, P. The preparation of cobalt phosphide and cobalt chalcogenide (CoX, X = S, Se) nanoparticles from single source precursors. J. Mater. Chem. 2010, 20. [CrossRef]

46. Tan, M.; Wang, X.; Wang, X.; Zou, X.; Ding, W.; Lu, X. Influence of calcination temperature on textural and structural properties, reducibility, and catalytic behavior of mesoporous $\gamma$-alumina-supported $\mathrm{Ni}-\mathrm{Mg}$ oxides by one-pot template-free route. J. Catal. 2015, 329, 151-166. [CrossRef]

47. Wang, H.; Li, X.; Lan, X.; Wang, T. Supported ultrafine NiCo bimetallic alloy nanoparticles derived from bimetal-organic frameworks: A highly active catalyst for furfuryl alcohol hydrogenation. ACS Catal. 2018, 8, 2121-2128. [CrossRef]

48. Liu, Y.; Sotelo-Boyás, R.; Murata, K.; Minowa, T.; Sakanishi, K. Hydrotreatment of vegetable oils to produce bio-hydrogenated diesel and liquefied petroleum gas fuel over catalysts containing sulfided Ni-Mo and solid acids. Energy Fuels 2011, 25, 4675-4685. [CrossRef] 
49. Wang, W.; Li, L.; Tan, S.; Wu, K.; Zhu, G.; Liu, Y.; Xu, Y.; Yang, Y. Preparation of $\mathrm{NiS}_{2} / / \mathrm{MoS}_{2}$ catalysts by two-step hydrothermal method and their enhanced activity for hydrodeoxygenation of p-cresol. Fuel 2016, 179, 1-9. [CrossRef]

50. Patil, S.J.; Vaidya, P.D. On the production of bio-hydrogenated diesel over hydrotalcite-like supported palladium and ruthenium catalysts. Fuel Process. Technol. 2018, 169, 142-149. [CrossRef]

51. Onyestyák, G.; Harnos, S.; Szegedi, Á.; Kalló, D. Sunflower oil to green diesel over Raney-type Ni-catalyst. Fuel 2012, 102, 282-288. [CrossRef]

52. Kim, S.K.; Han, J.Y.; Lee, H.-S.; Yum, T.; Kim, Y.; Kim, J. Production of renewable diesel via catalytic deoxygenation of natural triglycerides: Comprehensive understanding of reaction intermediates and hydrocarbons. Appl. Energy 2014, 116, 199-205. [CrossRef]

53. Pinto, F.; Varela, F.T.; Gonçalves, M.; Neto André, R.; Costa, P.; Mendes, B. Production of bio-hydrocarbons by hydrotreating of pomace oil. Fuel 2014, 116, 84-93. [CrossRef]

(C) 2020 by the authors. Licensee MDPI, Basel, Switzerland. This article is an open access article distributed under the terms and conditions of the Creative Commons Attribution (CC BY) license (http://creativecommons.org/licenses/by/4.0/). 